\title{
Ares: Brother, Commander, Deity or Son? A New Interpretation of the Ares Tombstone
}

The Ares tombstone, dating to the late Antonine period and kept in the British Museum under inv. number GRA 1973.4-22.1 [Sc. 2271], is one of the most beautiful examples of Roman sepulchral art to come out of Egypt. Although the stela has been studied many times before, scholars continue to be intrigued by its problematical relief, depicting two men with similar facial features standing erect beside each other. A Greek epitaph, inscribed underneath the relief, informs us that the stela was set up for Ares, a veteran. A second Ares is mentioned, but his identity and relationship to the deceased are uncertain. Various theories have been proposed $\left({ }^{1}\right)$, identifying this Ares successively as a brother, commander or fellow soldier of the deceased, as Ares, the god of war, or as the deceased himself, but all of them have been refuted. The subject therefore needs to be revisited.

\section{The Ares tombstone}

The precise findspot of the tombstone is unknown, but there are indications that it came from the military necropolis at Nikopolis, near Alexandria in Egypt $\left(^{2}\right)$. More than hundred tombstones, most of them associated with the long-resident legio II Traiana fortis, were found during illegal excavations or turned up on the antiquities market in the late nineteenth

(1) K. Parlasca, in: K. Parlasca \& H. Seemann, Augenblicke. Mumienporträts und ägyptische Grabkunst aus römischer Zeit, Frankfurt 1999, 254-255 no. 159; A. ŁAJTAR, 'A Tombstone for the Soldier Ares (Egypt, Late Antonine Period)', JJP 32 (2002), 45-48; J. BingEN, 'Bulletin épigraphique', REG 116 (2003), 675-676 no. 615; AE 2002, 601-602 no. 1586; O. STOLL, " QQuod miles vovit...» oder: Der doppelte Ares. Bemerkungen zur Grabstele eines Veteranen aus Alexandria', $A K B 35$ (2005), 65-76; A. ChAniotis e.a. (eds.), in: SEG LII (2002), 608-609 no. 1762; AE 2005, 567 no. 1609.

(2) E.A. BrecciA, Alexandrea ad Aegyptum. Guide de la ville ancienne et moderne et du musée gréco-romain, Bergamo 1914, 73-74; B. TKACzOw, The Topography of Ancient Alexandria. An Archaeological Map, Warsaw 1993, 174-175; R. ALsTon, Soldier and Society in Roman Egypt. A Social History, London 1995, 192-193.

Chronique d'Égypte LXXXVII (2012), fasc. 174 - doi: 10.1484/J.CDE.1.103134 
and early twentieth century. The bulk is currently kept in the Graeco-Roman Museum at Alexandria, but the other tombstones are scattered over various collections (Athens, Bologna, Brussels, Warsaw, Brooklyn, etc.). Approximately $90 \%$ are made of marble, and more than half of the tombstones depict the deceased in high relief $\left(^{3}\right)$. The depiction of the man on the left of the Ares stela, representing a soldier, strongly resembles the soldiers' and veterans' stelae from Nikopolis $\left({ }^{4}\right)$. Furthermore, the altar form $\left({ }^{5}\right)$ and the symbol L for 'year' $\left(^{6}\right)$ also suggest an Egyptian origin. The tombstone first belonged to the private collection of Matthew Duane (1707-1785), an Irish lawyer and art patron $\left({ }^{7}\right)$. After his death, his elaborate collection was sold. Although the buyer of the Ares tombstone is not listed in the catalogue of the Duane Sale $\left({ }^{8}\right)$, the renowned collector Charles Townley (1737-1805) $\left({ }^{9}\right)$ may have purchased the stela, since he is known to have bought extensively at the auction. On 12 July 1805 , Townley's collection, also known as the Townley Marbles, was acquired by the British Museum by an Act of Parliament and the stela subsequently ended up in its collection.

\section{A. Description of the relief scene}

The small $(59.9 \times 39.3 \mathrm{~cm}$.), round-topped tombstone (FIG. 1) is made of gray, blue-veined marble from Asia Minor. The edges of the stone are

(3) I am currently preparing a catalogue of the Nikopolis tombstones, which is funded by a research grant of the Fonds Wetenschappelijk Onderzoek Vlaanderen. This project is referred to by J.C.N. Coulston, 'Art, Culture and Service: The Depiction of Soldiers on Funerary Monuments of the 3rd Century AD', in L. DE BLoIs \& E. Lo CASCIO (eds.), The Impact of the Roman Army (200 B.C. - A.D. 476). Economic, Social, Political, Religious and Cultural Aspects, Leiden - Boston 2007, 537 n. 34.

(4) L. Castiglione, 'Kunst und Gesellschaft im römischen Ägypten', AAntHung 15 (1967), 115 n. 38; P. NoelKe, 'Ein neuer Soldatengrabstein in Köln', in: Studien zu den Militärgrenzen Roms III, Stuttgart 1986, 224-225; S. SCHмIDT, Grabreliefs im griechisch-römischen Museum von Alexandria, Berlin 2003, 37-43, 126-134.

(5) G. SouKIASSIAN, 'Les autels "à cornes" ou "à acrotères" en Égypte', BIFAO 83 (1983), 317-333; J. QuAEGeBeur, 'L'autel-à-feu et l'abattoir en Égypte tardive', in: J. QuAegeBeur (ed.), Ritual and Sacrifice in the Ancient Near East, Leuven 1993, 329-353.

(6) B.F. CooK, 'The Townley Marbles in Westminster and Bloomsbury', Collectors and Collections, The British Museum Yearbook 2 (1977), 69 no. 5.

(7) D.G.C. Allan, 'Duane, Matthew (1707-1785)', in: Oxford Dictionary of National Biography [online publication: http://www.oxforddnb.com/view/article/8111].

(8) Sale Catalogue, ' 13 June 1785, first day's sale', 6 no. 42 ; referred to by Cook, 'The Townley Marbles' (1977), 69 no. 5.

(9) B.F. Cook, 'Townley, Charles (1737-1805)', in: Oxford Dictionary of National Biography [online publication: http://www.oxforddnb.com/view/article/27601]. 

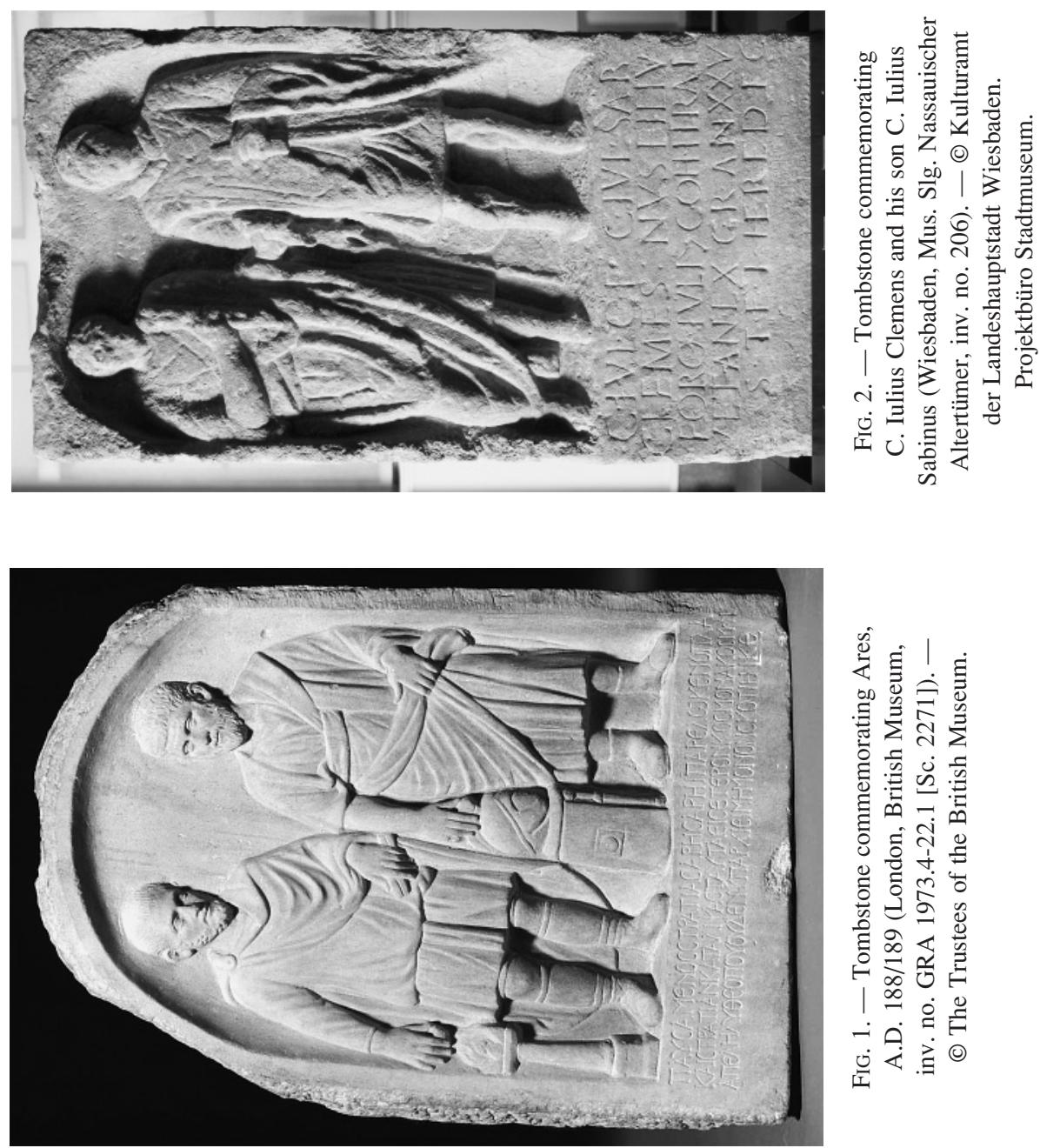

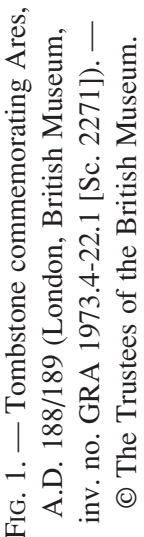


chipped and the right edge is scratched and damaged. The bottom edge is irregular and the extreme lower right corner is missing. Both the relief scene and the inscription area are smoothly dressed, but the edges are roughly finished with the chisel. Given the diminutive size, the tombstone may originally have been part of a larger funerary complex, similar to the tombstones found in the tombs on the edge of Terenouthis (Kom Abou Billou) $\left({ }^{10}\right)$. The stela exhibits excellent workmanship, in particular the relief scene: the faces, clothes and footwear of the two depicted men are executed with great care and attention to detail.

A large, recessed field, framed by a plain, round-topped border, narrow at the top and sides, with a relief scene takes up almost the whole surface of the stone. Two shorthaired, bearded men are standing erect beside each other, facing the front. The man on the left, his head slightly turned to the sinister, represents a soldier, dressed in a long-sleeved, wrist- and kneelength tunic. A sagum, fastened by a circular fibula at the dexter shoulder, falls open to reveal the dexter side of the chest, hanging down the back to behind the calves. Around the waist, the soldier wears a belt, hidden from view behind the pleats of the tunic, but its presence is suggested by the vertical strokes underneath, the belt causing the fabric of the garment to pleat into three triangular-shaped folds. He may also be wearing tight, fulllength breeches, tied at the back of the calves, knees and just below the knees $\left({ }^{11}\right)$. His feet are covered with a pair of boots with a heart-shaped cut-out at the toe and with broad, integral laces, similar to the boots found at Dura Europos in Syria $\left({ }^{12}\right)$. Since the dexter leg is slightly bent, the soldier is presumably leaning on the sinister leg. In his dexter hand, he is holding a patera $\left({ }^{13}\right)$, offering on a burning horned altar $(\mathrm{h} .14 .7 \mathrm{~cm}$.), on which a pinecone may be recognized. The object in his sinister hand,

(10) F.A. Hooper, Funerary Stelae from Kom Abou Billou, Ann Arbor 1961, esp. 1-3; K. PARlascA, 'Zur Stellung der Terenuthis-Stelen. Ein Gruppe römischer Grabreliefs aus Ägypten in Berlin', MDAIK 26 (1970), 173-198. Other forms of funerary monuments in Egypt are described by K. PARLASCA, 'Formen der Grabkunst im römischen Ägypten', Nürnberger Blätter zur Archäologie 9 (1992-1993), 125-128; STOLL, "«Quod miles vovit...»' (2005), 68.

(11) STOLL, " Quod miles vovit...»' (2005), 65. SUMNER is more cautious, leaving open the possibility that the soldier is wearing leg wrappings and leg bindings: G. SUMNER, Roman Military Clothing II: A.D. 200-400, Oxford 2003, 36.

(12) S. JAMES, The Arms and Armour and Other Military Equipment, London 2004, 59.

(13) E. PotTIER, 'Patera', in: Dictionnaire des antiquités grecques et romaines IV.1 (1963), 341. 
consisting of two oblong, parallel elements, may be a (double) scroll or booklet (diptychon) $\left({ }^{14}\right)$.

The head of the man on the right is turned to the dexter, in this way appearing as the other's mirror image. He has the same facial features as the man on the left, but the lines in his face suggest that he was older. His hair and beard also appear somewhat fuller and longer. He is dressed in a civilian fashion, wearing a long, calve-length tunic and relatively short toga, the free end of which he is holding in his sinister hand. The umbo (tightened and flattened over the sinister shoulder) and balteus are worn in a manner similar to statues found at Alexandria and appear in Roman sculpture from the late Antonine period onwards $\left({ }^{15}\right)$. He also wears a pair of ankle-high calcei. Since the sinister foot is turned outwards, his full weight is placed on the dexter leg. With his dexter hand he is reaching for the plume of a helmet $\left({ }^{16}\right)$ with large cheek pieces and a prominent brow band, placed on top of what appears to be a semi-cylindrical case. A short, sheathed sword and a curved, rectangular shield, which has a circular umbo surrounded by a rectangular plate, stand on the ground in front of this case. The handle assembly of the parallel-edged sword contains a rectangular hand guard, a plain handgrip and a spherical pommel. The scabbard ends in a plain, circular chape, typical from the second half of the second century onwards. The unit to which Ares had belonged is not recorded in the funerary inscription, but the curved, rectangular shield suggests that he had been a legionary $\left({ }^{17}\right)$, serving in legio II Traiana

(14) A.H. SмIth, in: BM Cat. Sculpture III (1904), 287 no. 2271; F.H. MarshaLl, in: GIBM IV.2 (1916), 223 no. 1113; TH. BIRT, Die Buchrolle in der Kunst. Archäologisch-antiquarische Untersuchungen zum antiken Buchwesen, Leipzig 1907, 49: scroll; ŁAJTAR, 'A Tombstone for the Soldier Ares' (2002), 46: military diploma; BINGEN, 'Bulletin épigraphique' (2003), 675 no. 615: scroll, will or military diploma; STOLL, '«Quod miles vovit...»’ (2005), 68, 73 n. 2: scroll or two cases containing writing materials.

(15) Type $\mathrm{Cb}$ in H.R. GoetTE, Studien zu römischen Togadarstellungen, Mainz am Rhein 1990, 57-58; for the Alexandrian statues, see 144 no. 20, Pl. 37.5-6.

(16) Contrary to STOLL's suggestion (“"Quod miles vovit...»' (2005), 66-67) that the helmet shows all the characteristics of a Niederbieber helmet, a new type of infantry helmet introduced in the late second century, the helmet type can in fact not be precisely determined.

(17) M.C. Bishop \& J.C.N. Coulston, Roman Military Equipment. From the Punic Wars to the Fall of Rome, Oxford $2006^{2}$, 91. The shield depicted on the Ares tombstone may be the latest representation of a truly curved, rectangular shield in private art: the three legionaries, depicted on a mid-second-century tombstone from Croy Hill, have rectilinear shields; see J.C.N. Coulston, 'Three Legionaries from Croy Hill', in: J.C.N. Coulston (ed.), Military Equipment and the Identity of Roman Soldiers, Oxford 1988, 1-29, esp. 5-7. The shields of the testudines on the Marcus Aurelius Column at Rome and on the Arches 
fortis, the only remaining legionary force in Egypt from 132 onwards $\left({ }^{18}\right)$. The similarity in iconography between the Ares stela and the soldiers' and veterans' stelae from Nikopolis supports this view $\left({ }^{19}\right)$.

\section{B. Transcription and translation of the epitaph}

A Greek $\left({ }^{20}\right)$ epitaph is competently carved underneath the relief scene in even, well-spaced and well-centred letters:

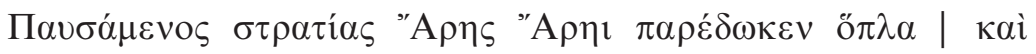

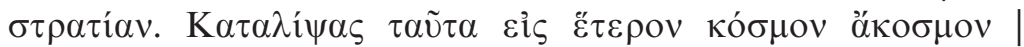

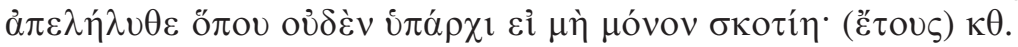

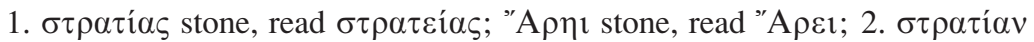

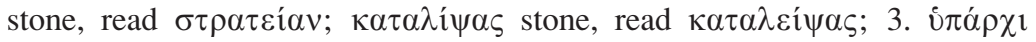
stone, read $\dot{\pi} \alpha \dot{\alpha} \rho \chi \varepsilon 1$.

After having ended his military service, Ares gave his arms and military appointment to Ares. After having left these things, he went on to another world that is no world, where there is nothing else except darkness. The 29th year.

The epitaph has a poetical undertone, both in composition and vocabu-

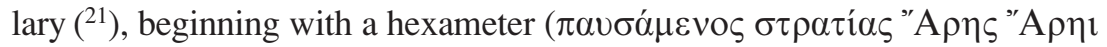

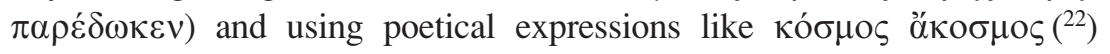

of Septimius Severus in the Forum Romanum and at Lepcis Magna are rectangular, but appear in a stylized, generic form, copied from Trajan's Column.

(18) E. RitTERLING, 'Legio (II Traiana)', in: RE XII.2 (1925), 1484-1493; J. LeSQUIER, L'armée romaine d'Égypte d'Auguste à Dioclétien, Cairo 1918, 26; S. DARIS, 'Legio II Traiana Fortis', in: Y. LE BoHEC \& C. WolfF (eds.), Les légions de Rome sous le HautEmpire I, Lyon 2000, 359-363; R. HaEnsch, 'The Roman Army in Egypt', in: C. RigGs (ed.), The Oxford Handbook of Roman Egypt, Oxford 2012, 68-82.

(19) CAstiglione, 'Kunst und Gesellschaft' (1967), 114-115; S. SchmidT, 'Tradition und Assimilation. Grabreliefs im griechisch-römischen Museum von Alexandria', in: H. Felber \& S. Pfisterer-HaAs (eds.), Ägypter, Griechen, Römer. Begegnung der Kulturen, Leipzig 1999, 1-25; SCHMIDT, Grabreliefs (2003), 37-43.

(20) The epitaphs inscribed on the Nikopolis tombstones are usually in Latin, rarely in Greek. Other examples of Greek epitaphs from Nikopolis are B.E. THOMASSON \& M. PAVESE (eds.), A Survey of Greek and Latin Inscriptions on Stone in Swedish Collections, Stockholm 1997, 117-118 no. 198; SB I 2477 and SEG VIII 358. For the use of Latin in the army in Egypt, see J.N. ADAMS, Bilingualism and the Latin Language, Cambridge 2003, 599-623.

(21) Greek epitaphs with a poetical undertone are common in the Greek East; see STOLL, '«Quod miles vovit...»' (2005), 73 n. 7.

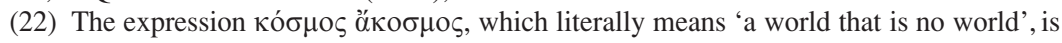
commonly used to refer to the underworld; see A. CHAniotis, 'Das Jenseits: eine Gegenwelt?', in: T. HÖLSCHER (ed.), Gegenwelten zu den Kulturen der Griechen und der Römer in 


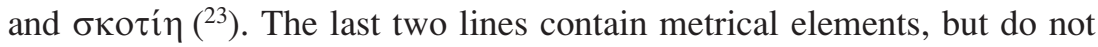
form complete verses. The author had thus clearly attempted to compose a metrical epitaph, but had not succeeded into producing metrically correct verses, especially not towards the end of the epitaph $\left({ }^{24}\right)$. These metrical mistakes may betray a Latin influence $\left({ }^{25}\right)$. Two important events that had taken place in the life of the deceased Ares are described in the epitaph: (1) his retirement from the army, after which he left his arms and his military appointment to another person, also called Ares, and (2) his subsequent death. Although the interpretation of the relief scene is still under discussion, it is clear that the first event is depicted $\left({ }^{26}\right)$. The relief thus differs somewhat from the usual reliefs on legionary tombstones, as described by Coulston $\left({ }^{27}\right)$.

\section{IDENTIFYING THE “SECOND” ARES}

The epitaph, in particular the interpretation of $\pi \alpha \rho \varepsilon \delta \omega \kappa \varepsilon v(1.1)$ and of the symbol L (1. 3), and the relief scene are much debated. The key problem is the presence of the second person, also called Ares, who is depicted on the relief and presumably mentioned in the epitaph, but whose identity and relationship to the deceased remain uncertain. Various theories have therefore been proposed.

\section{A. Identifying Ares: Brother, commander, fellow soldier, deity or deceased}

The first editors of the Ares tombstone, Smith and Marshall $\left({ }^{28}\right)$, provided neither a translation of the epitaph nor an interpretation of the relief scene. Both of them, however, thought that $\mathrm{L}$ indicates the age of the

der Antike, Munich - Leipzig 2000, 159-188, esp. 159 n. 1; R.A. Tyвout, 'Naar een andere wereld. Verkenningen van het Griekse grafepigram op steen', Lampas 36 (2003), 351 n. 88.

(23) R. LATtimore, Themes in Greek and Latin Epitaphs, Urbana 1942, 161-164 §39.

(24) ŁAJTAR, 'A Tombstone for the Soldier Ares' (2002), 46.

(25) I am much indebted to Willy CLARYSSE for his help with the metrical composition of the epitaph.

(26) ŁAJTAR, 'A Tombstone for the Soldier Ares' (2002), 47.

(27) Coulston, 'The Depiction of Soldiers on Funerary Monuments' (2007), 533-534: 'The deceased may stand leaning on one or more shafted weapons, generally spears (...). Alternatively, the man may hold a rotulus in his left hand and either be twirling his beltstrap in his right, or pouring a libation on an altar or thymiaterion by his side.'

(28) SMITH, in: BM Cat. Sculpture III (1904), 287 no. 2271; MARSHALl, in: GIBM IV.2 (1916), 223 no. 1113. 
deceased ( $\dot{\varepsilon} \tau \tilde{\omega} v)$. Cook $\left({ }^{29}\right)$ was the first scholar who interpreted the relief scene, stating that a soldier called Ares dedicated his arms to the homonymous war god upon his discharge (not depicted on the relief). The custom of offering arms as vota to Ares was indeed widespread in the Roman world (e.g., CIL VIII 2634 of 253 ) $\left(^{30}\right)$. Cook made no attempt, however, to identify the man shown on the left of the relief scene. Most of the scholars who studied the Ares tombstone followed Cook's interpretation of the relief: only Bingen proposed a different interpretation (see below). They did attempt, however, to identify the man on the left and his relationship to the deceased. Parlasca $\left({ }^{31}\right)$ thought that the depicted men were brothers, a view that explains their strong physical resemblance. The considerable age difference, however, suggests that they were father and son, as will be argued below. Parlasca also believed that the symbol L stands for Ë $\tau$ ous, the regnal year, dating the stela to $187 / 188\left({ }^{32}\right)$.

Łajtar $\left.{ }^{33}\right)$, who translated $\pi \alpha \rho \varepsilon ́ \delta \omega \kappa \varepsilon v$ as 'offered', identified the man on the right as the deceased veteran Ares and the man on the left as the commander of the unit in which Ares had served (not recorded in the epitaph). The object, held in the sinister hand of the commander, might be a military diploma, handed over to Ares on the occasion of his honourable discharge from the army. Following this interpretation, however, Ares was not a legionary, because legionary veterans did not normally receive diplomas (PSI IX 1026, col. A, 1. 22-23; col. B, 1. 15 and col. C, 1. 31-32: veterani ex legionibus instrumentum accipere non solent) $\left({ }^{34}\right)$. Since the military equipment, depicted on the relief, suggests that the deceased was a legionary, an alternative interpretation of the object, and of the relief in general, is necessary. Łajtar correctly dated the stela to

(29) Cоoк, 'The Townley Marbles' (1977), 69 no. 5.

(30) O. Stoll, 'Entlassungsweihungen aus Bostra und die honesta missio. Epigraphische Reflexe eines römischen Heereszeremoniells', Jahrb. RGZM 49 (2002), 272-273 n. 224.

(31) Parlasca, in: Parlasca \& Seemann, Augenblicke (1999), 255 no. 159.

(32) P. BURETH, Les titulatures impériales dans les papyrus, les ostraca et les inscriptions d'Égypte (30 a.C.-284 p.C.), Brussels 1964, 87-92; D.M. KIENAST, Römische Kaisertabelle. Grundzüge einer römischen Kaiserchronologie, Darmstadt 1996², 148. Commodus, who continued the era of his father Marcus Aurelius, was the only emperor who reigned for twenty-nine years. PARLASCA slightly miscalculated the regnal year, since the 29th year corresponds to $188 / 189$.

(33) ŁaJTAR, 'A Tombstone for the Soldier Ares' (2002), 46.

(34) S. Waebens, 'The Legal Status of Legionary Recruits in the Principate: A Case Study (Lucius Pompeius Niger, A.D. 31-64)', in: Y. Le BoHec (ed.), Actes du Congrès de Lyon (23-25 septembre 2010), Paris forthcoming. 
188/189 ( $\mathrm{L}=$ Ë $\tau$ ov $\varsigma$ ), noting that the iconographical details of the relief scene (the serene facial expressions, the deep incisions used to render the hair and beard and the manner in which the toga is depicted) support this date.

Bingen $\left({ }^{35}\right)$ proposed a new interpretation of the relief scene, arguing that $\pi \alpha \rho \varepsilon \delta \delta \omega \kappa \varepsilon v$ should be translated as 'transmitted' and that the second Ares mentioned in the epitaph was not the war god Ares, but a person. He identified the man on the left as the soldier Ares, who died aged twenty-nine $(L=\dot{\varepsilon} \tau \tilde{\omega} v)$, after having left his arms to one of his fellow soldiers, also called Ares, who is depicted on the right. Although Ares was a common name in Roman Egypt $\left({ }^{36}\right)$, particularly among soldiers, it seems unlikely that two soldiers of the same unit shared the same name, as noted by the editors of SEG LII.

Stoll $\left({ }^{37}\right)$ argued that both figures represent the same person, Ares, but in different stages of his life: on the left, he is portrayed as a young soldier; on the right, as a veteran in tunic and toga. After Ares had been discharged, he dedicated his arms, depicted on the relief, to the homonymous war god (mentioned in the epitaph, but not shown on the relief scene) to carry out his promise made as a soldier (compare with RIU III 876, dating after 297: quod miles votavit vet(eranus) solvit - "what he promised as a soldier he will carry out as a veteran') $\left({ }^{38}\right)$. When a soldier was honourably discharged, he was released from the military oath sworn on enlistment in an official ceremony (sacramentum solvere), during which he laid down his arms, as argued by Stoll. The man on the left may thus represent the tiro or miles Ares, shown in the process of swearing a votum before entering the army officially $\left({ }^{39}\right)$, and the man on the right the veteran Ares, shown in the process of dedicating his arms to the homonymous god. Following this view, the symbol $L$ stands for हैं

(35) BINGEN, 'Bulletin épigraphique' (2003), 675-676 no. 615.

(36) Several dozens of attestations in F. PREISIGKE, Namenbuch, Heidelberg 1922, 47; D. ForaboschI, Onomasticon alterum papyrologicum. Supplemento al Namenbuch di F. Preisigke, Milan 1971, 47 and in the Trismegistos database, 13/10/2011 (http://www. trismegistos.org/).

(37) STOLL, '«Quod miles vovit...»' (2005), 70-72.

(38) Other examples of soldiers' and veterans' dedications of arms to deities are CIL XIII 3592 from Germania Inferior (legio III Cyrenaica: a centurion's dedication of his spears and scutum to Vihansa); CIL III $14433^{1}$ from Moesia Inferior (Durostorum: scutum and spatha) and SEG XLVII 2061 of unknown provenance (legio X Fretensis: a veteran's dedication of his spears to Zeus Olybreus).

(39) For this military oath, see J.B. CAmpBell, The Emperor and the Roman Army, 31 B.C. - A.D. 235, Oxford 1984, 23-32. 
the regnal year, rather than for $\dot{\varepsilon} \tau \tilde{\omega} v$, the soldier's age at death, since Ares must have been much older than twenty-nine when he died. The main problem with this view is the singularity of the 'doppelte Ares': although Stoll gives examples of figures represented twice or more on Roman sarcophagi $\left({ }^{40}\right)$, these figures are always part of larger, narrative scenes (friezes) that are separated from each other, as noted by the editors of SEG LII. The doubling of a single figure on a stela in one and the same relief scene thus appears to be unparalleled $\left({ }^{41}\right)$.

The editors of SEG LII identified the man on the left as the soldier Ares, who died at the age of twenty-nine $(L=\dot{\varepsilon} \tau \tilde{\omega} v)$, and the man on the right as the war god Ares, portrayed with the arms he had received from the soldier as an attribute. In their view, the poetical undertone of the epitaph suggests a deeper meaning of the iuxtaposition "A $\rho\rceil \varsigma^{\text {"A }} \mathrm{A} \rho \mathrm{\imath}$

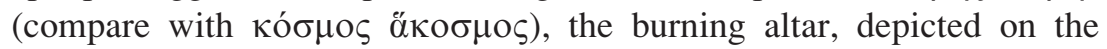
relief, symbolizing the contact between the human and divine sphere. Given the strong physical resemblance between the two depicted men, however, this interpretation is unlikely. The depiction of the man on the right also does not fit in with the usual depiction of the war god Ares or Mars, who may be naked, semi-naked (wearing a cloak only) or fully cuirassed, but who is always armed with shield, helmet and spear. Furthermore, no animals sacred to him are shown on the relief scene. But if the man depicted on the left is neither the deceased himself nor the god Ares, who is he then?

\section{B. Identifying Ares: Son and heir}

The starting point is the epitaph itself, especially the interpretation of

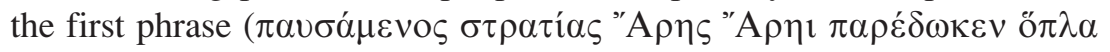

(40) Stoll, '«Quod miles vovit...»' (2005), 70.

(41) The deceased soldier Titus Flavius Mikkalus is shown mounted on a horse, riding between two sets of soldiers, on a late first-century funerary monument from Perinthus ( $A E$ 1987, no. $903=S E G$ XXXV $828=P M E q$ IV 60 bis). It is now generally accepted that the relief depicts his promotion from tribunus legionis to praefectus alae, a promotion that is also mentioned in the fragmentary epitaph: H. DeviJver, 'T. Flavius Mikkalus, Ritteroffizier aus Perinthos', ZPE 64 (1986), 253-256 = The Equestrian Officers of the Roman Imperial Army, Amsterdam 1989, 390-395; DeVIJVER, The Equestrian Officers (1989), 435-437 no. 4, 445 no. 3; J. Dolata, 'Promotio militaris - die Beförderung eines ritterlichen Offiziers', Klio 77 (1995), 255-265; M.H. SAYAR, Perinthos-Herakleia (Marmara Ereglisi) und Umgebung. Geschichte, Testimonien, griechische und lateinische Inschriften, Vienna 1998, 257-259 no. 72. The deceased is, however, portrayed only once, in the centre of the relief scene. 


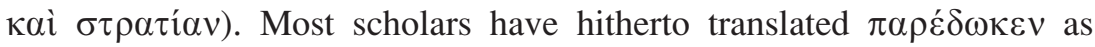
'offered' and have interpreted the relief scene as the dedication of Ares' arms to the homonymous god upon his discharge. The correct translation of $\pi \alpha \rho \varepsilon ́ \delta \omega \kappa \varepsilon v$ is, however, 'gave' or 'transmitted', as Bingen noted $\left({ }^{42}\right)$. The relief scene should also not necessarily be interpreted as the offering of Ares' arms to the deity: the relief merely shows Ares in the process of laying his dexter hand on a group of arms, standing on the ground beside him. Moreover, $\sigma \tau \rho \alpha \tau i ́ \alpha v$ (Łajtar and Stoll: 'military discipline', Bingen: 'inscription au role de l'armée' $\left({ }^{43}\right)$ ) is very difficult to interpret within an offering context. Neither the epitaph nor the relief scene thus implies that Ares dedicated his arms to Ares upon his discharge. On the contrary, the phrasing of the epitaph (1. 2: $\kappa \alpha \tau \alpha \lambda i$ i $\alpha \varsigma$ ), resembling the standard phrasing used in Greek copies of Latin wills on papyrus or wood ( $\delta$ í $\delta \omega \mu$ i $\kappa \alpha \tau \alpha \lambda \varepsilon i \pi \omega\left({ }^{44}\right)$ and $\left.\kappa \alpha \tau \alpha \lambda \varepsilon i ́ \pi \omega\left({ }^{45}\right)\right)$, supports the view that the second Ares mentioned in the epitaph was a person, not a deity. Combined, the relief scene and the epitaph thus suggest that the deceased veteran Ares left his arms and his military appointment to another person, also called Ares.

Given the physical resemblance between the two depicted men $\left({ }^{46}\right)$, the shared name and the age difference, the man on the right presumably represents the deceased veteran Ares, who is shown in the process of handing over his arms to his son, also called Ares, who is portrayed on the left of the relief $\left({ }^{47}\right)$. In Roman Egypt, about $8 \%$ (980 out of 12,048) of all male children were named after their father and it is therefore plausible that the

(42) Bingen, 'Bulletin épigraphique' (2003), 676 no. 615. For this interpretation of $\pi \alpha \rho \varepsilon ́ \delta \omega \kappa \varepsilon v$, see John Chrysostom, De precatione, Oratio II (PG 50) 784.34. I would like to thank Wilfried VAN RENGEN for this reference.

(43) For this interpretation of $\sigma \tau \rho \alpha \tau i \alpha \nu$, see Dio 72.12.3.

(44) E.g., P. Oxy. XXXVIII 2857, 1. 18-19 (14 May 134); Pap. Lugd. Bat. XIII 14, 1. 8, 12-13 (127-148); BGU VII 1655, 1.9 (3 June 169); P. Diog. 9, 1. 11, 18-20 (186-210); $B G U$ I 326, 1. 18, 39-40 (189-194); P. Strasb. IV 277, 1.8 (second half of the third century).

(45) E.g., P. Oxy. XXXVIII 2857, 1. 20, 24 (14 May 134); Pap. Lugd. Bat. XIII 14, 1. 16 (127-148); BGU I 326, 1. 24, 31 (189-194); P. Hamb. I 73, 1. 9-10 (second century); P. Princ. II 38, 1. 6 (c. 264?); P. Col. VII 188, 1. 7 (14 March 320).

(46) Although Roman tombstones were mass-produced and most of the funerary portraits were stylized, I believe that the physical resemblance between the two men on the Ares tombstone represents their kinship rather than the stonemason's incapability to depict distinctive portrait traits. The excellent workmanship that the stela exhibits and the unusual choice of depiction of the deceased, support the view that the tombstone was not a standard product of a military workshop.

(47) I would like to thank Katelijn VANDORPE for suggesting this possibility to me. 
two men were father and son $\left({ }^{48}\right)$. A comparison with other second- and third-centuries tombstones, on which two full-length standing male figures are shown, supports this view, because they usually represent a father and son or two brothers (see table I). Since the possibility that the relief on the Ares tombstone portrays two brothers has already been ruled out due to the considerable age difference, the most plausible view is that a father and son are depicted. There are two possibilities then: Ares could have been born before or after his father's discharge from the army. If he had been born after his father's discharge, he would have been a legitimate child, able to inherit from his father. But if he had been born during his father's military service, the situation would have been more complicated.

The inheritance problems of soldiers' and veterans' illegitimate children require discussion in more detail here, since the epitaph suggests that Ares left his son his arms and his military appointment, i.e., his military post $(\sigma \tau \rho \alpha \tau i \alpha v)$. Soldiers were still subject to a marriage ban in the late Antonine period, prohibiting them to contract legal Roman marriages during their military service: any child born to them while they were serving in the army was therefore illegitimate (Latin: spurius, Greek: å $\pi \alpha \tau_{\omega} \rho$ and $\chi \rho \eta \mu \alpha \tau i \zeta \omega \nu \mu \eta \tau \rho o ́ \varsigma)\left({ }^{49}\right)$ and not their automatic heir $\left({ }^{50}\right)$. This simply means, however, that the father had no legal obligation to support his illegitimate children: if he did wish to provide for his children, he could legate to them in his will $\left({ }^{51}\right)$. If he died intestate, however, the woman

(48) The figures are based on the Trismegistos database, 10/06/2010 (http://www.trismegistos.org/). In Ptolemaic Egypt, c. 5.2\% of all male children had the same name as their paternal (or maternal) father $(\mathrm{N}=17,318)$.

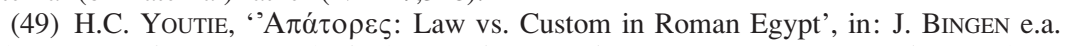
(eds.), Le monde grec: pensée, littérature, histoire, documents. Hommages à Claire Préaux, Brussels 1975, 732, 737; M. MaloutA, 'The Terminology of Fatherlessness in Roman Egypt: $\alpha \dot{\alpha} \alpha \omega \rho$ and $\chi \rho \eta \mu \alpha \tau i ́ \zeta \omega \nu \mu \eta \tau \rho o ́ \varsigma '$, in: J. FRÖSÉN e.a. (eds.), Proceedings of the 24th International Congress of Papyrology. Helsinki, 1-7 August 2004, Helsinki 2007, 619.

(50) For a detailed study of the soldiers' marriage ban, see S.E. PHANG, The Marriage of Roman Soldiers (13 B.C. - A.D. 235). Law and Family in the Imperial Army, Leiden 2001. Although it is generally assumed that the marriage ban was lifted under Septimius Severus, a recently published auxiliary diploma of 206 suggests otherwise: W. EcK, 'Septimius Severus und die Soldaten. Das Problem der Soldatenehe und ein neues Auxiliardiplom', in: B. ONKEn \& D. RoHDE (eds.), Studien zur Geschichte von der Antike bis zur Neuzeit, Wiesbaden 2011, 63-77.

(51) For the soldier's will, see M. AMELOTTI, Il testamento romano attraverso la prassi documentale, Florence 1966, 74-75, 81-110; E. Champlin, Final Judgments. Duty and Emotion in Roman Wills, 200 B.C. - A.D. 250, Berkeley 1991, 51, 56-59; CAMPBELL, The Emperor and the Roman Army (1984), 210-229; PHANG, The Marriage of Roman Soldiers (2001), 217-221. 
with whom he had been living during his military service and the illegitimate children born out of this union had no right to claim his property. In 119 ( $B G U$ I 140), Hadrian improved the situation of the soldiers' and veterans' illegitimate children by granting them the right of bonorum possessio unde cognati, i.e., the right to claim intestate inheritance from their fathers: if their fathers died intestate, they would inherit as if their fathers had no legitimate children. Consequently, whether Ares was born before or after his father's discharge, he would have been permitted to inherit

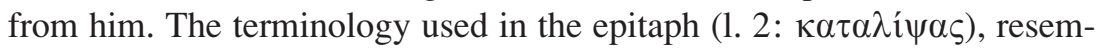
bling the standard phrasing used in Greek copies of Latin wills on papyrus or on wood ( $\delta i \delta \omega \mu 1 \kappa \alpha \tau \alpha \lambda \varepsilon i ́ \pi \omega$ and $\kappa \alpha \tau \alpha \lambda \varepsilon i ́ \pi \omega)$, supports this view. Since the relief scene depicts the transmission of Ares' arms to his son, the object, held in the son's sinister hand, may be his father's will, written on papyrus or wood $\left({ }^{52}\right)$. Heirs are occasionally shown on their benefactors' tombstones: the tombstone of Marcus Caelius, for instance, a centurio of legio XVIII who died in the 'Varian war' in A.D. $9\left({ }^{53}\right)$, shows the deceased flanked by the busts of his freedmen Marcus Caelius Privatus and Marcus Caelius Thiaminus.

One may wonder, however, whether soldiers and veterans could leave their arms as part of their inheritance. The evidence clearly attests that soldiers owned their own military equipment, which they bought from the army (the money was deducted from their pay) $\left({ }^{54}\right)$ or acquired privately upon enlistment. Claudius Terentianus, for instance, who had shortly before joined the Misene fleet, asks his friend, Claudius Tiberianus $\left({ }^{55}\right)$, in an early second-century letter to send him the following (P. Mich. VIII 467, 1. 17-21): gladiu [m pu]gnatorium et $l$...am et d[o]labram et copla [m] et lonchas duas quam byrrum castalinum et tunicam bra[c]ilem cum bracis meis ut habeam - 'a battle sword, a ..., a pickaxe, a grappling iron, two of the best spears obtainable, a ... cloak, and a girdled tunic, together with my trousers, so that I may have them.' Since the arms were their private property, soldiers were free to dispose of them as they wished. In

(52) Soldiers' wills are often recorded on wooden tablets; see J. BINGEN, 'Miles armorum custos (CIL, III, Suppl., 14138², Alexandrie)', in: P. Defosse (ed.), Hommages à Carl Deroux. III, Histoire et épigraphie, droit, Brussels 2003, 67: 'Le rouleau peut même être remplacé par des tablettes, qui évoquent encore mieux le testament.'

(53) CIL XIII 8648 [Ubi Erat Lupa, no. 15513].

(54) R.W. DAviEs, 'Joining the Roman Army', BJ 169 (1969), 223-224 = R.W. DAVIES, Service in the Roman Army, Edinburgh 1989, 19-20 [edited by D.J. BREEZE \& V.A. MAXFIELD].

(55) S. StRASsi, L'archivio di Claudius Tiberianus da Karanis, Berlin 2008, 109-112. 
P. Vindob. L 135 of A.D. 27, for instance, the cavalryman Lucius Caecilius Secundus pawns his silver-inlaid helmet, silver-inlaid insigne, and silver and ivory dagger scabbard to Caius Pompeius. But what happened to these arms upon the soldier's death or discharge? In most cases, the soldier's unit bought his arms, regardless whether they were army property or privately owned. In several soldiers' wills, the value of the arms in general is listed as part of the inheritance (e.g., P. Col. VIII 221 of 143: 21 denarii and $27 \frac{1}{2}$ obols in armis). In these cases, the heirs received the money due to them rather than the arms themselves, perhaps because they were civilians $\left.{ }^{56}\right)$. Nonetheless, many soldiers' wills list the actual arms as part of the inheritance (e.g., CPL 221 of 142; P. Col. VII 188 of 320). MacMullen listed several pieces of military equipment (helmets, swords, shields, etcetera) with the names of their successive owners $\left({ }^{57}\right)$, but it is unclear in these cases whether the arms had been bought back by the army or left as personal property to heirs. Pieces of military equipment could also be buried with their owners or dedicated to deities as votives, as argued above, attesting to the private ownership of arms $\left({ }^{58}\right)$.

Ares did not only leave his arms to his son, but also his military appointment, i.e., his military post. This part of Ares' inheritance is puzzling, since a military post could not be passed on from father to son, at least not until the fourth century. Nevertheless, there were ways to ensure that the son ended up serving in the same unit or holding the same post as his father, as the papyri attest. Fathers might put in a good word for sons: in $P$. Oxy. XIV 1666, a third-century letter, Pausanias tells his brother about his journey to Alexandria. After having enlisted in legio II Traiana fortis, his son, also called Pausanias, had changed his mind, preferring military service in the cavalry $\left.{ }^{59}\right)$. At the request of his wife and daughter, Pausanias went to Alexandria to bring the matter before the authorities and eventually succeeded in obtaining the prefect's permission for the transfer

(56) D.J. BREEZE, 'The Ownership of Arms in the Roman Army', Britannia 7 (1976), 93-95. Gilliam, however, is more cautious, see J.F. GILLIAM, 'The Deposita of an Auxiliary Soldier (P. Columbia inv. 325)', BJ 167 (1967), 237-238 = Roman Army Papers, Amsterdam 1986, 321-322.

(57) R. MacMullen, 'Inscriptions on Armor and the Supply of Arms in the Roman Empire', AJA 64 (1960), 33-39.

(58) J.F. Gilliam, 'Notes on a New Latin Text: P. Vindob. L 135', ZPE 41 (1981), 279280 = Roman Army Papers (1986), 431-432; M.P. SPEIDEL, 'The Weapons Keeper, the Fisci Curator and the Ownership of Weapons in the Roman Army', in: M.P. SPEIDEL, Roman Army Studies II, Stuttgart 1992, 134.

(59) For the reason of this transfer, see VEGETIUs, Epitoma rei militaris 2.3. 
to an ala at Coptos $\left({ }^{60}\right)$. It might also have been useful for recruits to possess letters of recommendation from influential persons who could pull strings for them when asked: Iuvenal, for instance, advises recruits to arm themselves with the best possible letters of recommendation they could obtain (16.5-6). A copy of the second-century epistula commendaticia, written by the beneficiarius Aurelius Archelaus to his tribunus militum Iulius Domitius, is partially preserved $\left({ }^{61}\right)$. A well-known example of a legionary who used the connections of his father to rise within the ranks of the army is G. Iulius Apollinarius ( $\left.{ }^{62}\right)$. On 26 March 107, he writes to his father, G. Iulius Sabinus, that thanks to the legatus legionis Claudius Severus, he had been promoted to the post of librarius legionis ad spem promotionis, having become an immunis within three years of enlisting in legio III Cyrenaica, a not inconsiderable achievement $\left({ }^{63}\right)$. His letters, most notably P. Mich. VIII 466 of 105, also show him using his own influence for others $\left({ }^{64}\right)$.

Since Ares is depicted as a soldier on the relief scene, he was probably serving in the army at the time of his father's discharge and subsequent death, having followed in his father's footsteps $\left({ }^{65}\right)$. We do not know to which unit he belonged or in what military rank he served, but the phrasing of the epitaph does suggest that he held the same military post as his father. Ares may therefore have chosen to depict the transmission of his father's arms and military post to himself on the tombstone that he had commissioned for his father. Following this interpretation, Ares was shown on the relief scene while still living, but the depiction of living

(60) Another example of fathers pulling strings for their sons to advance their military careers is $P$. Mich. VIII 485 of 105 . For a recent discussion of this letter, see S. STRASSI, 'P. Mich. VIII 485: alcune considerazioni', ZPE 139 (2002), 161-176.

(61) P. Oxy. I $32=C P L 249=C h L A$ IV 267. For more examples: DAVIES, 'Joining the Roman Army’ (1969), 216-217.

(62) For an overview of Apollinarius' military career, see K. STRobEL, 'Zu Fragen der frühen Geschichte der römischen Provinz Arabia and zu einigen Problemen der Legionsdislokation im Osten des Imperium Romanum zu Beginn der 2. Jh. n. Chr.', ZPE 71 (1988), 258-260; STRAsSI, 'P. Mich. VIII 485' (2002), 163-164.

(63) P. Mich. VIII 466.

(64) The letters of Iulius Apollinarius and his father Iulius Sabinus are mainly published in $P$. Mich. VIII and IX.

(65) Most veterans' sons tended to follow their fathers into military service, often at their fathers' encouragement; see G. WESCH-KLEIN, 'Recruits and Veterans', in: P. ERDKAMP (ed.), A Companion to the Roman Army, Oxford 2007, 436. 
family members on tombstones is frequently attested, especially in third-century Danubian regions $\left({ }^{66}\right)$.

\section{CONCLUSION}

The aim of this paper was to propose a new interpretation of the relief scene on the Ares tombstone, since the identity of a second person, shown on the left, and his relationship to the deceased, shown on the right, are still debated. Most scholars have hitherto interpreted the relief as the dedication of Ares' arms to the homonymous war god upon his discharge. Here it has been argued, however, that neither the relief scene nor the Greek epitaph supports this view. On the contrary, the phrasing of the epitaph (particularly the use of $\pi \alpha \rho \varepsilon \delta \delta \omega \kappa \varepsilon v$ and $\kappa \alpha \tau \alpha \lambda i \psi(\alpha \varsigma$ and the interpretation of $\sigma \tau \rho \alpha \tau i \alpha \nu$ ) suggests that the relief scene depicts the transmission of Ares' arms to another person, also called Ares. Given the physical resemblance between the two depicted men, the shared name and the age difference, the most plausible view is that they were in fact father and son. A comparison with other second- and third-centuries tombstones, on which two full-length standing male figures are shown, confirms that they generally represent a father and son or brothers. The considerable age difference between the two men, depicted on the Ares stela, points to a father-son relationship. Although the Ares stela will undoubtedly continue to intrigue scholars, this paper has hopefully led to a better understanding of the Greek epitaph and the corresponding relief scene $\left({ }^{67}\right)$.

Katholieke Universiteit Leuven, Ancient History Sofie WAEBENS

(66) E.g., Pannonia Inferior: RIU V 1191, 1217; Tituli Aquincenses II 546; Pannonia Superior: RIU III 694; Syria: CIL III 14165; Noricum: CSIR Lauriacum 38; Britannia: Coulston, 'Three Legionaries from Croy Hill' (1988), 1-29; Egypt: SCHMIDT, Grabreliefs (2003), 129 no. 111.

(67) The Ares stela was presented as a case study at the second Third Century Colloquium on 3 September 2009 at Leuven and during a seminar on 23 February 2011 at the Kommission für Alte Geschichte und Epigraphik des Deutschen Archäologischen Instituts (Munich). I would like to thank those present for their comments on the material discussed. I am also grateful to Katelijn VANDORPE, Jon COULSTON and Adam ŁAJTAR for reading and commenting on earlier drafts of this paper. Furthermore, I am much indebted to Peter HiGGS, curator of the Department of Greek and Roman Antiquities at the British Museum, for permission to publish the tombstone. 


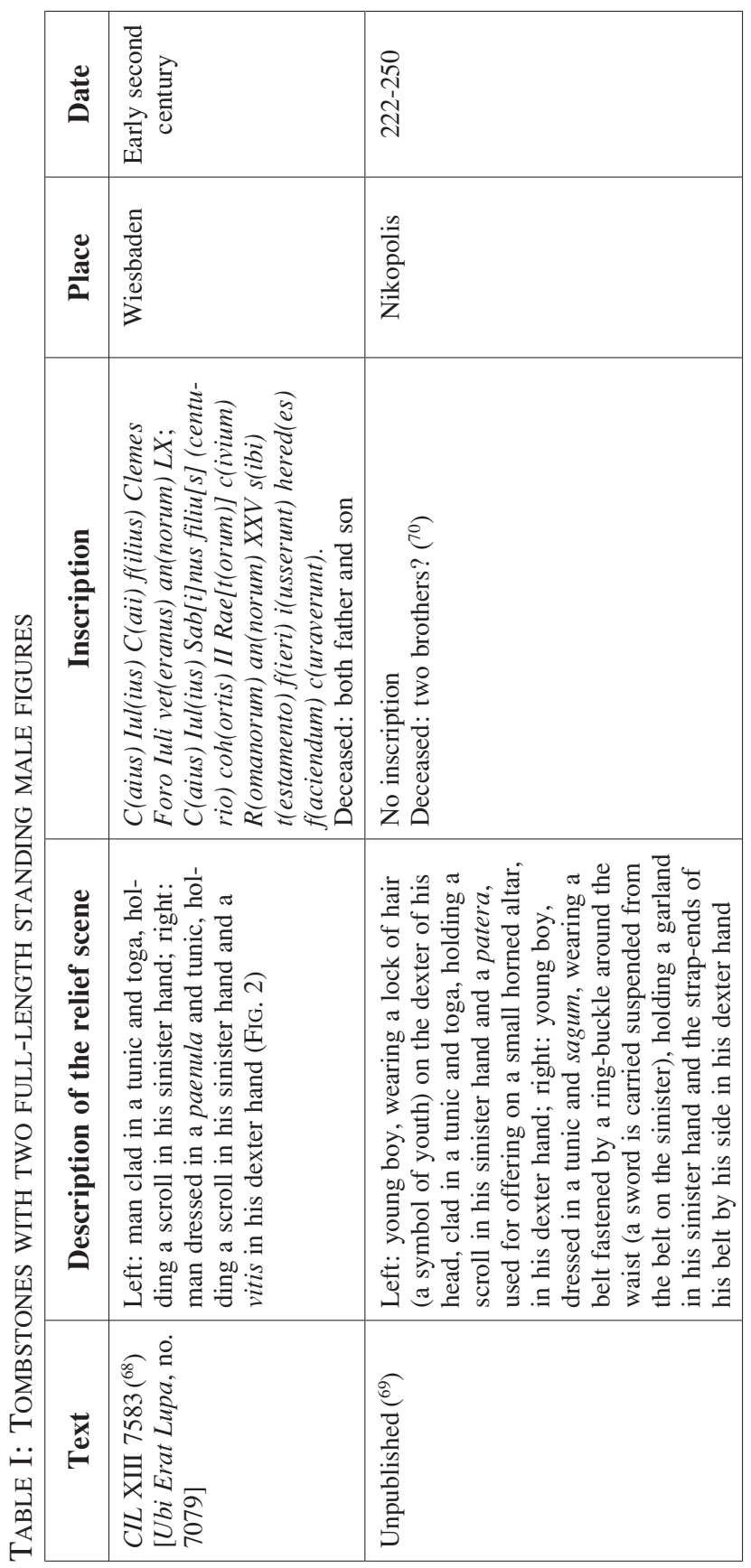

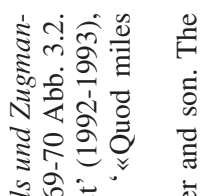

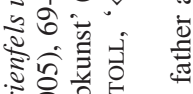

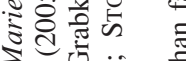

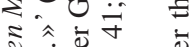
苛要

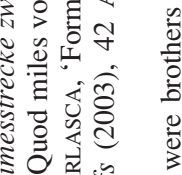
包造

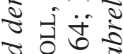

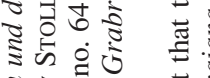

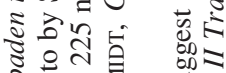

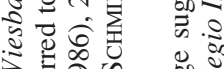

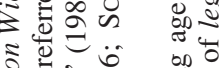

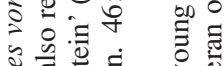

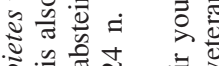

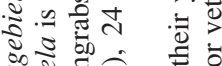

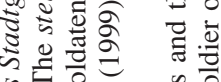
on

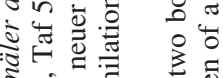

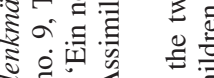
अ 2

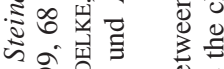

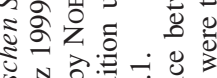

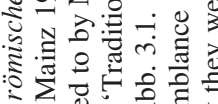

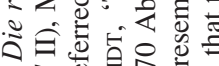

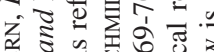

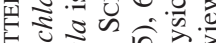

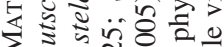

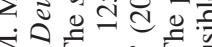

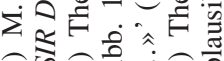

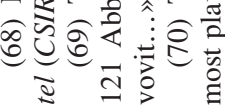



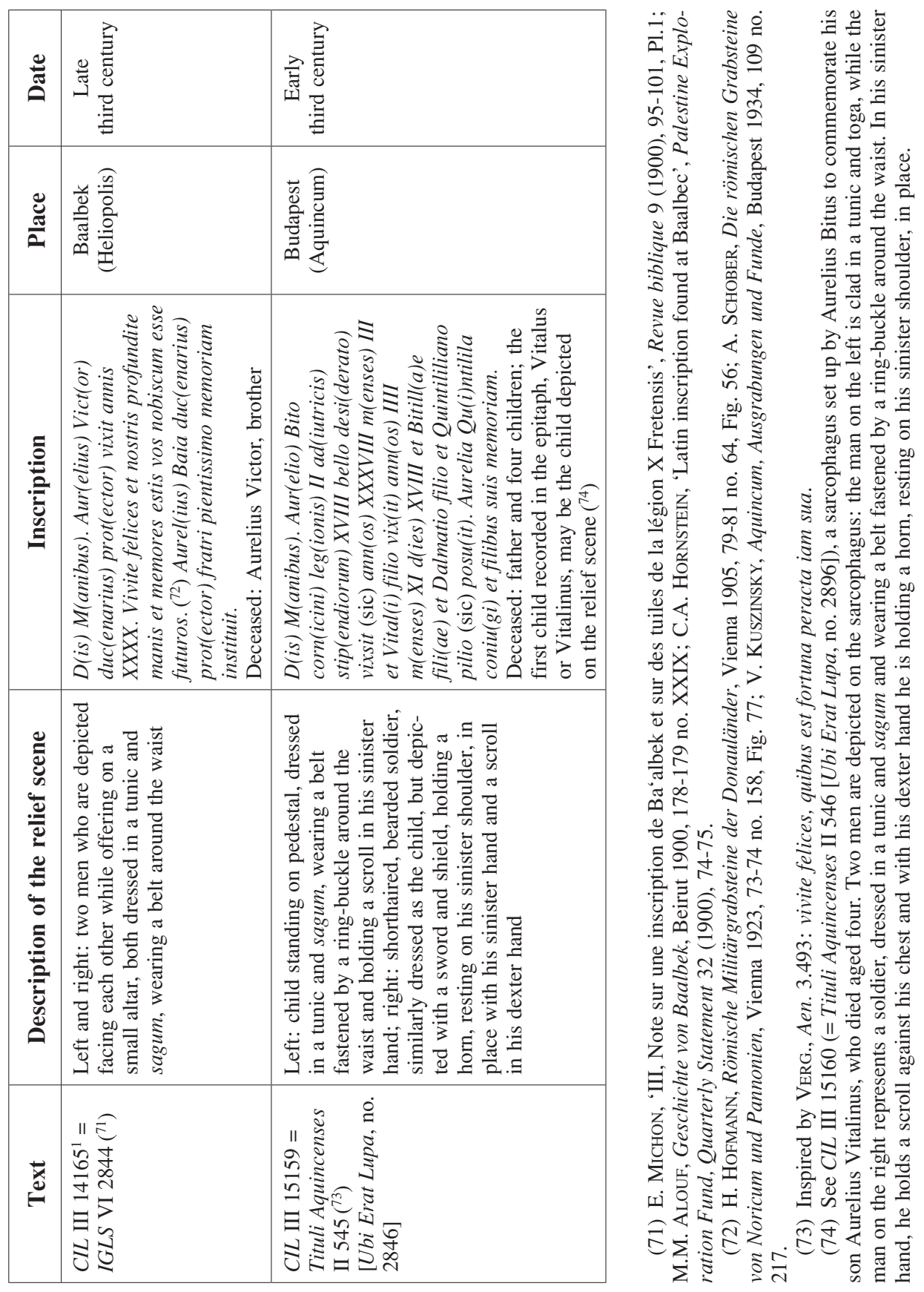